2016-11-15

\title{
Minimally invasive cardiac surgery: $A$ systematic review and meta-analysis
}

\section{Dieberg, G}

http://hdl.handle.net/10026.1/6655

10.1016/j.jjcard.2016.08.227

INTERNATIONAL JOURNAL OF CARDIOLOGY

Elsevier BV

All content in PEARL is protected by copyright law. Author manuscripts are made available in accordance with publisher policies. Please cite only the published version using the details provided on the item record or document. In the absence of an open licence (e.g. Creative Commons), permissions for further reuse of content should be sought from the publisher or author. 


\title{
Minimally invasive cardiac surgery: a systematic review and meta-analysis.
}

\author{
Gudrun Dieberg PhD ${ }^{1}$, Neil A. Smart $\mathrm{PhD}^{1}$ \& Nicola King PhD
}

1. School of Science and Technology, University of New England, Armidale, NSW 2350, Australia. These authors take responsibility for all aspects of the reliability and freedom from bias of the data presented and their discussed interpretation.

2. School of Biomedical and Healthcare Sciences, Plymouth University Peninsula Schools of Medicine and Dentistry, University of Plymouth, Plymouth, PL4 8AA, UK. This author takes responsibility for all aspects of the reliability and freedom from bias of the data presented and their discussed interpretation.

Address for Correspondence: School of Biomedical and Healthcare Sciences Plymouth University Peninsula School of Medicine and Dentistry University of Plymouth Plymouth, PL4 8AA, UK.

Tel: +44 1752584969

e-mail: nicola.king@plymouth.ac.uk

\section{Funding source: none}

Conflicts of interest: none declared

Key words: Minimally invasive; cardiac surgery; ICU stay; cardiopulmonary bypass time Running head: Minimally invasive cardiac surgery

Word Count - Full text: 3,825 


\section{ABSTRACT}

Background: Minimally invasive (MI) cardiac surgery was introduced to reduce problems associated with a full sternotomy. This meta-analysis aimed to investigate the effects of minimally invasive cardiac surgery on a range of clinical outcomes.

Methods: To identify potential studies (randomised/propsective clinical trials) systematic searches were carried out. The search strategy included the concepts of "minimally invasive" OR "MIDCAB" AND "coronary artery bypass grafting" OR "cardiac surgery". This was followed by a meta-analysis investigating cross-clamp time, cardiopulmonary bypass (CPB) time, operation time, ventilation time, intensive care unit (ICU) stay, hospital stay, incidence of myocardial infarction and of stroke/neurologic complications.

Results: Eight studies (9 intervention groups), totalling 596 participants were analysed. MI cardiac surgery was associated with a shorter ICU stay mean difference (MD) -0.7 days (95\% confidence interval $(\mathrm{Cl})-1.23$ to $-0.18, \mathrm{p}=0.009)$ and longer cross-clamp MD 6.7 minutes $(95 \%$ $\mathrm{Cl} 1.24$ to $12.17, \mathrm{p}=0.02$ ), CPB MD 26.68 minutes ( $95 \% \mathrm{Cl} 10.31$ to $43.05, \mathrm{p}=0.001$ ), and operation times MD 55.03 minutes $(95 \% \mathrm{Cl} 22.76$ to $87.31, \mathrm{p}=0.0008)$. However no differences were found in the ventilation time MD -3.94 hours ( $95 \% \mathrm{Cl}-8.09$ to $0.21, p=0.06$ ), length of hospital stay MD -1.14 days $(95 \% \mathrm{Cl}-3.11$ to $0.83, p=0.26)$ and in the incidence of myocardial infarction odds ratio (OR) 1.97 ( $95 \% \mathrm{Cl} 0.49$ to $7.9, \mathrm{p}=0.34)$ or stroke / neurologic complications OR 0.67 (95\% $\mathrm{Cl} 0.11$ to $4.05, \mathrm{p}=0.66)$.

Conclusions: Minimally invasive cardiac surgery is as safe as conventional surgery and could reduce costs due to a shorter period spent in ICU.

Word count: 250 
Accepted on $16^{\text {th }}$ August 2016

\section{INTRODUCTION}

Coronary artery bypass grafting (CABG) was first introduced in the 1960s [1], and, despite the rise of percutaneous coronary intervention, remains the standard of care for high risk patients including those with diabetes and/or complex left main or triple vessel disease [1-2]. The majority of CABG operations still involve a median sternotomy and use cardiopulmonary bypass combined with aortic cross-clamping and cardioplegic arrest. This can represent a frightening prospect for some patients with regard to having the chest 'cracked open' [1]. Minimally invasive cardiac surgery, where access to the heart is typically achieved through a left or right minithoracotomy, may alleviate this problem. The incision is smaller and the risks of wound infection following sternal trauma and problems with sternum healing are avoided [1]. Other possible benefits of minimally invasive cardiac surgery include a reduction in post-operative atrial fibrillation [3], reduced length of hospital stay [4] with earlier mobilisation of patients [5] and cost-effectiveness compared to traditional on-pump CABG [4]. Surgeons have also stated that anastomosing the left internal mammary artery to the left anterior descending artery is easier via minimally invasive cardiac surgery via a left minithoracotomy than a median sternotomy [6].

Minimally invasive cardiac surgery is not without its problems. Inadequacy of heart exposure with a left minithoracotomy may account for an increase in operation time and perioperative complications [7]. In the short term, patients may experience more pain due to involvement of the intercostal nerves [3] and excessive rib retraction [8]. The procedure is also more technically demanding [9]. One study has also reported that minimally invasive surgery increases ventilation time [5], although it should be noted that the majority of cases report shorter ventilation times [9-12]. 
The aims of this meta-analysis were to: i) investigate the effects of minimally invasive cardiac surgery on a range of clinical outcomes including cross-clamp time, cardiopulmonary bypass time, operation time, ventilation time, ICU and hospital stay, incidence of perioperative myocardial infarction, and incidence of stroke/neurologic complications; and ii) relate these findings to established thresholds of clinical significance and provide an evidence based context for the use of minimally invasive cardiac surgery.

\section{METHODS}

\section{Search strategy}

To identify potential studies systematic searches were carried out using the following databases: EMBASE, PubMed, Web of Science and the Cochrane Central Registry of Controlled Trials (CENTRAL). The search was supplemented by scanning the reference lists of eligible studies. The search strategy included the key concepts of "minimally invasive" AND "coronary artery bypass grafting" OR "MIDCAB" OR "cardiac surgery". All identified papers were assessed independently by two reviewers. A third reviewer was consulted to resolve disputes. Searches of published papers were conducted up until April 1st, 2016.

\section{Types of studies to be included and excluded}

Only randomized controlled trials (RCTs) and prospective trials of patients undergoing minimally invasive cardiac surgery vs. surgery via a median sternotomy were included. There were no language restrictions. Animal studies, review papers and retrospective trials were excluded. Studies that did not have any of the desired outcome measures were excluded. Incomplete data, or data from an already included study, were excluded. Other treatment 
modalities and interventions for coronary artery disease such as percutaneous coronary intervention were excluded. Other treatment modalities for valvular disease such as balloon valvuloplasty were excluded.

\section{Participants/population}

This meta-analysis analysed RCTs and prospective trials of both male and female adult $(\geq 18$ years) patients with coronary artery disease or valvular disease who were undergoing cardiac surgery using either minimally invasive cardiac surgery or cardiac surgery through a median sternotomy.

Intervention(s), exposure(s)

This meta-analysis considered all RCTs and prospective trials where patients with stable angina or acute coronary syndrome being treated with CABG or patients with valvular disease were exposed to either a median sternotomy or minimally invasive surgery. More specifically, all RCTs and prospective trials where the intervention of carrying out cardiac surgery without the use of a median sternotomy was performed.

\section{Search Results}

Our initial search found 4,490 articles. Of these 4,345 studies were excluded on the basis of title and abstract. 128 studies were excluded as they were not RCTs or prospective trials. Of the RCTs and prospective trials we excluded 9 studies: 6 studies that were retrospective analyses; 2 studies that had no comparator group; and 1 study that had no reported outcomes (see supplementary Figure S1). Eight studies (9 intervention groups) were included in our analysis [5, 8-14]. 


\section{Outcome(s)}

The primary outcomes analysed were: cross-clamp time; cardiopulmonary bypass time; operation time; ventilation time; length of stay in the intensive care unit (ICU); length of hospital stay; incidence of myocardial infarction; and incidence of stroke / neurologic complications.

Risk of bias (quality) assessment

The modified JADAD scale was used to assess study quality and reporting [15].

\section{Strategy for data synthesis}

Odds ratios were calculated for dichotomous data. Mean differences were calculated for continuous data. Meta-analyses were completed for continuous data by calculating the mean difference between intervention and control groups from post-intervention data only. It is an accepted practice to only use post-intervention data for meta-analysis, but this method assumes that random allocation of participants always creates intervention groups matched at baseline for age, disease severity. All analyses were conducted using Revman 5.0 (Nordic Cochrane Centre, Denmark). A fixed effects inverse variance model was used unless heterogeneity was $>75 \%$, then a random effects model was used. Heterogeneity was quantified using the $\mathrm{I}^{2}$ test [16]. We used a $5 \%$ level of significance and $95 \%$ confidence intervals; figures were produced using Revman 5.3.

\section{RESULTS}

The 8 studies (9 intervention groups) [5, 8-14] included in the analyses had an aggregate of 596 participants, 298 of which had minimally invasive cardiac surgery and 298 had 
Accepted on $16^{\text {th }}$ August 2016

conventional cardiac surgery via a median sternotomy. Table 1 summarizes the characteristics of the included studies. Supplementary Table S1 lists the excluded trials and reasons for exclusion.

\section{Cross-clamp time}

Five studies reported the cross-clamp time in minutes. The mean difference (MD) for the pooled analysis was MD 6.7 minutes (95\% confidence interval $(C I) 1.24$ to $12.17, I^{2}=91 \%$, $p=0.02$ ), see Figure 1 . Cross-clamp times were significantly longer in the minimally invasive group.

\section{Cardiopulmonary Bypass Time}

Five studies reported the cardiopulmonary bypass (CPB) time in minutes. The mean difference for the pooled analysis was MD 26.68 minutes ( $95 \% \mathrm{Cl} 10.31$ to $43.05, \mathrm{I}^{2}=96 \%$, $p=0.001$ ), see Figure 2. CPB times were significantly longer in the minimally invasive group.

\section{Operation time}

Four studies (5 intervention groups) reported the operation time in minutes. The mean difference for the pooled analysis was MD 55.03 minutes $\left(95 \% \mathrm{Cl} 22.76\right.$ to $87.31, \mathrm{I}^{2}=95 \%$, $p=0.0008$ ), see Figure 3 . Minimally invasive cardiac surgery operations took a significantly longer time to complete compared to conventional cardiac surgery.

\section{Ventilation time}

Seven studies (8 intervention groups) reported the ventilation time in hours. The mean difference for the pooled analysis was -4.68 hours ( $95 \% \mathrm{Cl}-9.27$ to $\left.-0.1, \mathrm{I}^{2}=98 \%, \mathrm{p}=0.05\right)$, see 
Figure 4. There was a strong trend towards a shorter ventilation time in patients operated on by minimally invasive cardiac surgery; however, this failed to reach significance.

\section{Length of ICU stay}

Six studies reported the length of ICU stay in days. The mean difference for the pooled analysis was $\mathrm{MD}-0.7$ days $\left(95 \% \mathrm{Cl}-1.23\right.$ to $\left.-0.18, \mathrm{l}^{2}=92 \%, \mathrm{p}=0.009\right)$, see Figure 5 . Patients operated on by minimally invasive cardiac surgery had significantly shorter stays in ICU compared to those operated on by conventional median sternotomy.

\section{Length of hospital stay}

Five studies reported the length of hospital stay in days. The mean difference for the pooled analysis was -1.14 days $\left(95 \% \mathrm{Cl}-3.11\right.$ to $\left.0.83, \mathrm{l}^{2}=95 \%, \mathrm{p}=0.26\right)$, see Figure 6 . Although those operated on via minimally invasive cardiac surgery had a shorter hospital stay, there was no significant difference in the length of hospital stay between the two groups.

\section{Incidence of myocardial infarction}

Five studies (6 intervention groups) reported the incidence of myocardial infarction. The odds ratio for the pooled analysis was OR 1.97 (95\% $\mathrm{Cl} 0.49$ to $7.9, \mathrm{I}^{2}=0 \%, \mathrm{p}=0.34$ ), see Figure 7. There was no difference in the incidence of myocardial infarction between patients operated on by minimally invasive cardiac surgery compared to those operated on by conventional median sternotomy.

Incidence of stroke / neurologic complications

Four studies reported the incidence of stroke / neurologic complications. The odds ratio for the pooled analysis was OR $0.67\left(95 \% \mathrm{Cl} 0.11\right.$ to $\left.4.05, \mathrm{l}^{2}=0 \%, \mathrm{p}=0.66\right)$, see Figure 8 . There 
was no difference in the incidence of stroke or neurologic complications between patients operated on by minimally invasive cardiac surgery compared to those operated on by conventional median sternotomy.

\section{DISCUSSION}

To the best of our knowledge this is the first systematic review and meta-analysis that investigated minimally invasive versus conventional cardiac surgery. The results showed that minimally invasive surgery was associated with a significantly shorter stay in the ICU; a strong trend towards a shorter intubation time, no significant difference in length of hospital stay, whilst the time spent in the operating theatre was longer as was the time spent on cardiopulmonary bypass and cross-clamp. There was also no significant difference in the incidence of myocardial infarction or stroke/neurological complications. These results suggest that minimally invasive surgery has advantages and disadvantages compared to conventional surgery including the potential to reduce cost due to a shorter length of time spent in ICU.

Stroke is known to be a major cause of morbidity and mortality following CABG. The postoperative incidence of stroke ranges from 1.4 to $3.8 \%$ [17]. Risk factors that have been identified include prolonged cardiopulmonary bypass (CPB) time and postoperative atrial fibrillation [18]. CPB time was significantly longer in the minimally invasive group (see Figure 1), however the incidence of stroke or neurologic complications was not significantly different (Figure 6). In addition, in two separate studies Dogan et al $[5,8]$ examined neuropsychological function and found no difference between the minimally invasive versus conventional groups. Only one study reported the incidence of atrial fibrillation [11] where the occurrence was similar in both groups and there was no incidence of stroke in either 
group. These findings suggest that minimally invasive surgery is not associated with a higher incidence of stroke / neurologic complications, despite the longer cross-clamp, CPB and operation times. These longer times may reflect the greater technical difficulty involved in performing minimally invasive cardiac surgery. It should be noted that in four of the studies [9-12] off-pump cardiac surgery was performed; this completely removed the risk of long CPB and cross-clamp times and minimised aortic manipulation.

Minimally invasive surgery was associated with a significantly shorter stay in the ICU unit (Figure 3). Indeed in all but one [5] of the studies where length of ICU stay was investigated the ICU stay was shorter in the minimally invasive group [8-11, 13-14]. It has been reported that an increased stay in ICU is associated with a greater risk of mortality and higher hospital costs [19]. Therefore, minimally invasive cardiac surgery has the potential to reduce costs and reduce risk of mortality, although it should be noted that the length of hospital stay was comparable in the 2 groups. There was also a strong trend towards a reduced ventilation time in the MI group. This may lead to a decreased risk of ventilator associated pneumonia and airway trauma, and facilitate earlier mobilization and transfer to less stressful stepdown monitored units [20].

Perioperative myocardial infarction (MI) is a significant cause of morbidity and mortality following coronary artery bypass grafting (CABG) [21]. Diagnostic criteria varies including for example enzyme release or electrocardiographic criteria [21]. Perhaps, as a consequence of this the incidence of $\mathrm{MI}$ also varies between 10.8\% [21], 10.8\% [22] and 24.1\% [23]. Irrespective of these differences these studies consistently show a poorer outcome for those suffering perioperative $\mathrm{MI}$ whether this be in terms of having more cardiac events during 30 months of follow-up [22], poorer left ventricular function [23], or higher 30-day 
mortality [21]. In our meta-analysis the incidence of MI was not significantly different between the two groups. This suggests that minimally invasive cardiac surgery is noninferior compared to conventional cardiac surgery.

There are several limitations to this work. All of the continuous measurements were associated with high heterogeneity $\left(I^{2}>90 \%\right)$. It should be noted that heterogeneity for the dichotomous measures was $0 \%$. In addition there were differences in the type of surgery performed in the conventional group with some using off-pump methods [9-12] and others using on-pump methods $[5,8,10,13]$. Of those investigators who used on-pump methods the application of cardioplegia varied. Dogan et al $[5,8]$ used cold blood cardioplegia whilst Tünerir and Aslan [14] and Gulielmos et al [10] used cold crystalloid cardioplegia and Speziale et al [13] did not state which cardioplegia was used. The type of surgery also varied from CABG $[5,12,9-11]$ to valve replacement [8] to repair of Barlow mitral disease [13] to atrial septal defect repair and myxoma excision [14]. All of the studies were small and involved $<100$ patients in each group. The experience of the surgeon was not always mentioned.

\section{REFERENCES}

1. Head SJ, Börgermann J, Osnabrugge RLJ, Kieser TM, Falk V, Taggart DP et al: Coronary artery bypass grafting: part 2 - optimizing outcomes and future prospects. Eur Heart J 2013;34:2873-2886. 
2. Ruel M, Shariff MA, Lapierre H, Goyal N, Dennie C, Sadel SM et al: Results of the minimally invasive coronary artery bypass grafting angiographic patency study. J Thorac Cardiovasc Surg 2014;147:203-209.

3. Stamou SC, Bafi AS, Boyce SW, Pfister AJ, Dullum MKC, Hill PC et al: Coronary revascularization of the circumflex system: different approaches and long-term outcomes. Ann Thorac Surg 2000;70:1371-1377.

4. King RC, Reece TB, Hurst JL, Shockey KS, Tribble CG, Spotniz WD et al: Minimally invasive coronary artery bypass grafting decreases hospital stay and cost. Ann Surg $1997 ; 225: 805-809$.

5. Dogan S, Graubitz K, Aybek T, Khan MF, Kessler P, Moritz A et al: How safe is the port access technique in minimally invasive coronary artery bypass grafting? Ann Thorac Surg 2002;74:1537-1543.

6. Calafiore AM, Giammarco GD, Teodori G, Bosco G, D’Annunzio E, Barsotti A et al: Left anterior descending coronary artery grafting via left anterior small thoracotomy without cardiopulmonary bypass. Ann Thor Surg 1996;61:1658-1665.

7. Detter C, Reichenspurner H, Boehm DH, Thalhammer M, Schütz A, Reichart B. Eur J Cardio-thorac Surg 2001;19:464-470.

8. Dogan S, Dzemali O, Wimmer-Greinecker G, Derra P, Doss M, Khan MF et al: Minimally invasive versus conventional aortic valve replacement: a prospective randomized trial. J Heart Valve Disease 2003;12:76-80.

9. Güler M, Kirali K, Toker ME, Bozbuğa N, Ömeroğlu, Akinci E, Yakut C. Different CABG methods in patients with chronic obstructive pulmonary disease. Ann Thorac Surg 2001;71:152-157. 
10. Gulielmos V, Menschikowski M, Dill H-M, Eller M, Thiele S, Tugtekin SM et al: Interleukin-1, interleukin-6 and myocardial enzyme response after coronary artery bypass grafting - a prospective randomized comparison of the conventional and three minimally invasive surgical techniques. Eur J Cardio-thorac Surg 2000;18:594601.

11. Karpuzoglu OE, Ozay B, Sener T, Aydin NB, Ketenci B, Aksu T et al: Comparison of minimally invasive direct coronary artery bypass and off-pump coronary artery bypass in single-vessel disease. Heart Surg Forum 2009;12:E39-E43.

12. Rogers CA, Pike K, Angelini GD, Reeves BC, Glauber M, Ferrarini M et al: An open randomized controlled trial of median sternotomy versus anterolateral left thoracotomy on morbidity and health care resource use in patients having off-pump coronary artery bypass surgery: The sternotomy versus thoracotomy (STET) trial. J Thorac Cardiovasc Surg 2013;146:306-316.

13. Speziale G, Nasso G, Esposito G, Conte M, Greco E, Fattouch K et al: Results of mitral valve repair for Barlow disease (bileaflet prolapse) via right minithoracotomy versus conventional sternotomy: a randomized trial. J Thorac Cardiovasc Surg 2011;142:7783.

14. Tünerir B \& Aslan R: An alternative, less invasive approach to median sternotomy for cardiac operations in adults: right infra-axillary minithoracotomy. J Int Medical Res 2005;33:77-83.

15. Jadad AR, Moore RA, Carroll D, Jenkinson C, Reynolds DJ, Gavaghan DJ, McQuay HJ.: Assessing the Quality of reports of randomized clinical trials: is blinding necessary? Control Clin Trials. 1996;17:1-12. 
16. Higgins JPT, Altman DG, Gotzsche PC, Juni P, Moher D, Oxman AD, et al: The Cochrane Collaboration's tool for assessing risk of bias in randomized trials. Brit Med J. $2011 ; 343$.

17. Diodato $M$ and Chedrawy EG: Coronary artery bypass graft surgery: the past, present, and future of myocardial revascularisation. Surg Res Practice 2014; Article ID726158, 6 pages.

18. Mao Z, Zhong X, Yin J, Zhao Z, Hu X, Hackett ML: predictors associated with stroke after coronary artery bypass grafting: a systematic review. I Neurologic Sci 2015;357:1-7.

19. Pinto PP, Colangelo S, Bobbio M: Evolution of case-mix in heart surgery: from mortality risk to complication risk. Eur J Cardio-thorac Surg 2002;22:927-933.

20. Rodriguez-Blanco YF, Carvalhol EMF, Gologorsky A, Lo K, Salerno TA, Gologorsky E: Factors associated with safe extubation in the operating room after on-pump cardiac surgery. J Card Surg 2016;31:274-281.

21. Järvinen $\mathrm{O}$, Hokkanen $\mathrm{M}$, Huhtala $\mathrm{H}$ : The long-term effect of perioperative myocardial infarction on health-related quality-of-life after coronary artery bypass grafting. Interact Cardiovasc Thorac Surg 2014;18:568-573.

22. Force $T$, Hibberd P, Weeks G, Kemper AJ, Bloomfield P, Tow D et al: Perioperative myocardial infarction after coronary artery bypass surgery. Circ 1990;82:903-912.

23. Pretto P, Martins GF, Biscaro A, Kruczan DD, Jessen B. Perioperative myocardial infarction in patients undergoing myocardial revascularization surgery. Braz J Cardiovasc Surg 2015;30:49-54. 
List of Figures and Tables

Figure 1. Cross-clamp time (min)

Figure 2. Cardiopulmonary bypass time (min)

Figure 3. Operation time

Figure 4. Ventilation time (hours)

Figure 5. Length of ICU stay (days)

Figure 6. Length of hospital stay (days)

Figure 7. Incidence of myocardial infarction

Figure 8. Incidence of stroke / neurologic complications

Table 1. Included studies

Supplementary file

Figure S1. Consort statement

Table S1. Excluded studies

Table S2. Evaluation of study quality (modified Jadad scale) 
Table 1 - included studies

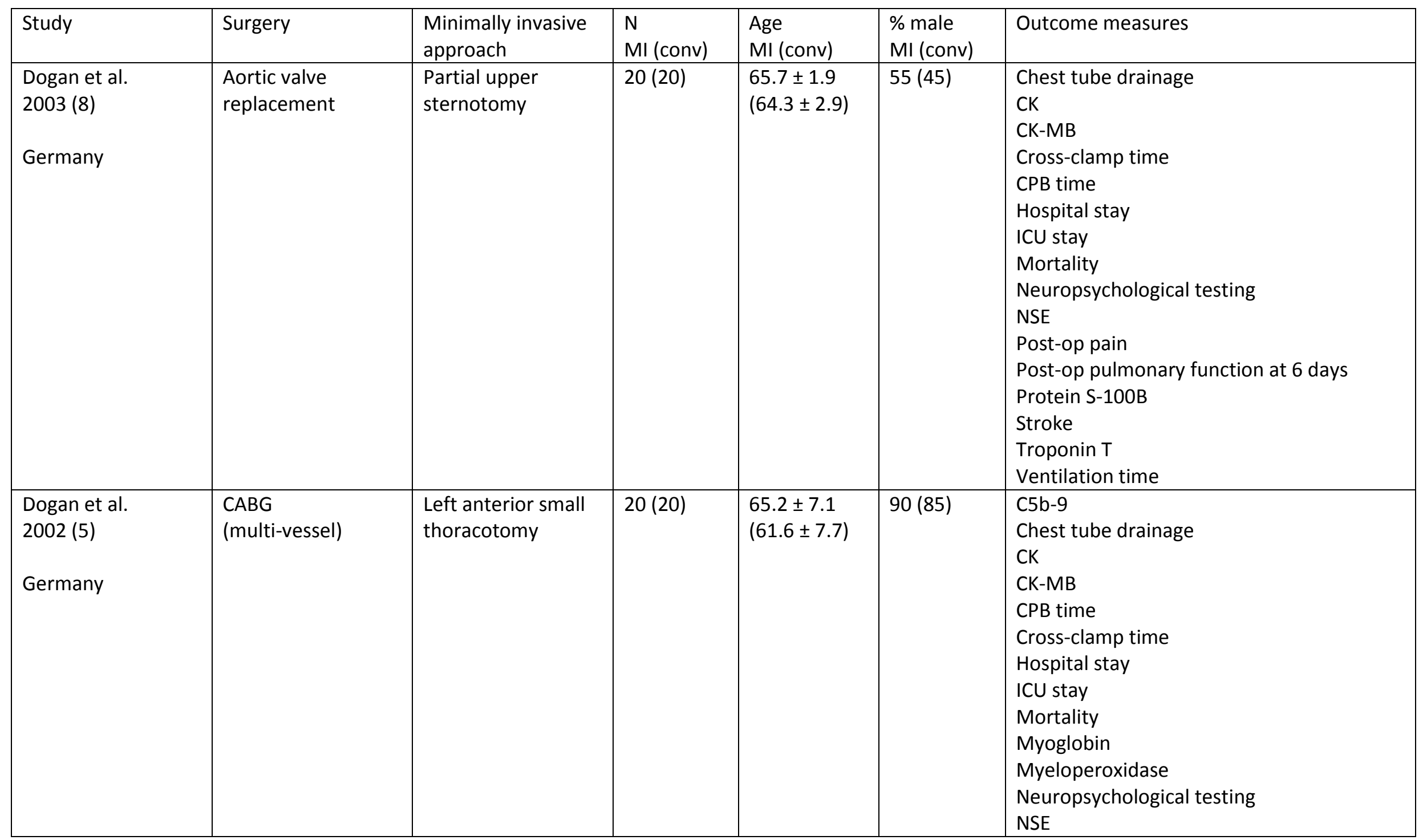




\begin{tabular}{|c|c|c|c|c|c|c|}
\hline & & & & & & $\begin{array}{l}\text { Post-op pain } \\
\text { Post-op pulmonary function at } 6 \text { days } \\
\text { Protein S-100B } \\
\text { Troponin T } \\
\text { Ventilation time }\end{array}$ \\
\hline $\begin{array}{l}\text { Güler et al. } \\
2001 \text { (9) } \\
\text { Turkey }\end{array}$ & $\begin{array}{l}\text { CABG } \\
\text { (single-vessel) }\end{array}$ & $\begin{array}{l}\text { Left anterior } \\
\text { minithoracotomy }\end{array}$ & $21(18)$ & $\begin{array}{l}52.3 \pm 8.6 \\
(54.1 \pm 9.0)\end{array}$ & NR & $\begin{array}{l}\text { ICU stay } \\
\text { Mortality } \\
\text { Myocardial infarction } \\
\text { Post-op pulmonary function at } 2 \text { days } \\
\text { Pulmonary complications at } 2 \text { months } \\
\text { Ventilation time }\end{array}$ \\
\hline $\begin{array}{l}\text { Gulielmos et al. } \\
(2000)(10) \\
\text { Germany }\end{array}$ & $\begin{array}{l}\text { On pump CABG } \\
\text { (single vessel) } \\
\text { Off pump CABG } \\
\text { (single vessel) }\end{array}$ & $\begin{array}{l}\text { Minithoracotomy } \\
\text { Minithoracotomy }\end{array}$ & $\begin{array}{l}10(10) \\
10(10)\end{array}$ & $\begin{array}{l}59.6 \pm 11 \\
(61.2 \pm 10.4) \\
65.1 \pm 10 \\
(62.9 \pm 9.8)\end{array}$ & $\begin{array}{l}80(70) \\
70(90)\end{array}$ & $\begin{array}{l}\text { CK-MB } \\
\text { CPB time } \\
\text { Cross-clamp time } \\
\text { Cytokines } \\
\text { Myocardial infarction } \\
\text { Operation time } \\
\text { Troponin T } \\
\text { Ventilation time }\end{array}$ \\
\hline $\begin{array}{l}\text { Rogers et al. } \\
2013(12) \\
\text { UK }\end{array}$ & $\begin{array}{l}\text { CABG } \\
\text { (multi-vessel) }\end{array}$ & $\begin{array}{l}\text { Left anterolateral } \\
\text { thoracotomy }\end{array}$ & $91(93)$ & $\begin{array}{l}63.1 \pm 8.7 \\
(66.7 \pm 8.0)\end{array}$ & $92(86)$ & $\begin{array}{l}\text { Hospital stay (median) } \\
\text { ICU stay (median) } \\
\text { Mortality } \\
\text { Myocardial infarction } \\
\text { Neurologic complications } \\
\text { Pain scores }\end{array}$ \\
\hline
\end{tabular}




\begin{tabular}{|l|l|l|l|l|l|l|}
\hline & & & & & $\begin{array}{l}\text { Pulmonary function at discharge } \\
\text { Quality of life scores } \\
\text { Ventilation time }\end{array}$ \\
\hline $\begin{array}{l}\text { Speziale et al. } \\
2011 \text { (13) }\end{array}$ & $\begin{array}{l}\text { Repair of Barlow } \\
\text { mitral disease } \\
\text { Italy }\end{array}$ & $\begin{array}{l}\text { Right } \\
\text { minithoracotomy }\end{array}$ & $70(70)$ & $\begin{array}{l}53.2 \pm 10.4 \\
(54 \pm 10.1)\end{array}$ & $59(61)$ & $\begin{array}{l}\text { CPB time } \\
\text { Cross-clamp time } \\
\text { Hospital stay } \\
\text { ICU stay } \\
\text { Mortality } \\
\text { Myocardial infarction } \\
\text { Neurologic complications } \\
\text { Post-op pain scores } \\
\text { Ventilation time }\end{array}$ \\
\hline $\begin{array}{l}\text { Tünerir \& Aslan } \\
2005 \text { (14) }\end{array}$ & $\begin{array}{l}\text { Valve disease, atrial } \\
\text { septal defect repair } \\
\text { and myxoma } \\
\text { excision }\end{array}$ & $\begin{array}{l}\text { Right infra-axillary } \\
\text { minithoracotomy }\end{array}$ & $29(30)$ & $42 \pm 6$ & $24(33)$ & $\begin{array}{l}\text { CPB time } \\
\text { Cross-clamp time } \\
\text { Hospital stay } \\
\text { ICU stay } \\
\text { Ventilation time }\end{array}$ \\
\hline
\end{tabular}

Abbreviations: AF - atrial fibrillation; C5b-9 - terminal complement complex; CABG - coronary artery bypass graft surgery; CK - creatine kinase; CK-MB creatine kinase myocardial band; conv - conventional; CPB time - cardiopulmonary bypass time; ICU - intensive care unit; MI - minimally invasive; NSE neuron-specific enolase; NR - not reported; and post-op - post-operative. 